\title{
ПЕСТИЦИДИ В ПІДЗЕМНИХ ВОДАХ УКРАЇНИ І ЗДОРОВ'Я
}

\section{ПЕСТИЦИДЫ В ПОДЗЕМНЫХ ВОДАХ УКРАИНЫ И ЗДОРОВЬЕ PESTICIDE CONTENT IN THE GROUNDWATER OF UKRAINE AND HEALTH}

(Матеріал друкуеться мовою оригіналу)

Досліджено вміст пестицидів у підземних водах України. Методом газової хроматографії визначено стійкі хлорорганічні пестициди (ХОП): дихлордифенілтрихлоретан (ДДТ) і його метаболіти, гексахлорциклогексан (ГХЦГ) і його ізомери, альдрин, гептахлор; фосфорорганічні пестициди: метафос, карбофос, фосфамід, фозалон; фторумісні пестициди: трефлан та ін.

31960 року по 2011 рік на сільгоспугіддя України надійшло 2 млн 85 тис. тонн пестицидів [4]. Навантаження пестицидів на грунти сільгоспугідь перевищило захисні властивості природного середовища, що призвело до потрапляння їх у підземну геосистему. За нашими розрахунками (за 10-річний період), середньостатистична концентрація ХОП в основних водоносних горизонтах України становить за сумою ДДТ 3,6·10-5 мг/дм³; за сумою ГХЦГ - 3·10 ${ }^{-5}$ мг/дм³. Водоносний горизонт четвертинних відкладів містить на один-два порядки менше стійких ХОП, ніж глибше розміщені водоносні горизонти крейдяних, юрських і тріасових відкладень. Найбільше забруднення пестицидами виявлено у водоносних горизонтах південної і центральної України, набагато менше забруднення спостерігається у водоносних горизонтах західного, східного та північного регіонів країни. У воді свердловин одночасно виявлено до восьми сільськогосподарських забруднювачів, сумарний ефект впливу яких на організм людини не вивчений. Оцінено вплив умісту пестицидів у підземних водах на рівень онкозахворюваності населення України [7].

Потрібен контроль і сувора регламентація обсягів того чи іншого класу пестицидних препаратів під час унесення їх на сільгоспугіддя. Потрібен регулярний контроль якості підземних вод і моніторинг забруднення пестицидами підземних вод та інших об'єктів природного середовища. Результати нових аналізів щодо забруднення об’єктів природного середовища пестицидами треба порівнювати з гранично допустимою концентрацією (ГДК). Якщо рівні забруднення об'єктів природного середовища пестицидами збільшуватимуться (перевищення ГДК), то треба зменшити навантаження пестицидів на сільгоспугіддя і замінити старі пестициди на нові. Також треба сформувати збалансовану систему природокористування в контексті сталого розвитку та впровадити екологічні й інноваційні технології в сільському господарстві за допомогою сучасних механізмів національної екологічної політики.

Ключові слова: підземні води, пестициди, захворюваність населення.

The examinations of groundwaters Ukraine for the content of strong organochloric pesticides: DDT and its metabolites, $\mathrm{HCCH}$ and its isomers, aldrin, heptachlor; organophosphoric pesticides: methaphos, carbophos, phosphomide, phozalone; fluorine-containing pesticides: trephlane and others using gas chromatography method were carried out.

From 1960 to 2011,2 million 85-thousand ton pesticides were received on agricultural lands of Ukraine [4]. The pressure of pesticides on the soils of farmland exceeded the protective properties of the natural environment, which led to their entry into the underground geosystem. According to our calculations (over a 10-year period), the average concentration of pesticides in the main aquifers of Ukraine is $3,6 \cdot 10^{-5} \mathrm{mg} / \mathrm{dm}^{3}$ for DDT, $3 \cdot 10^{-5} \mathrm{mg} / \mathrm{dm}^{3}$ for $\mathrm{HCCH}$. The aquifer of Quaternary sediments contains persistent organochloric pesticides 1-2 orders of magnitude less than the deeply located aquifers Cretaceous, Jurassic and Triassic sediments. Most contamination with pesticides is found in the aquifers of groundwater in southern and central Ukraine, much less pollution is observed in the aquifers of the western, eastern and northern regions of the country. At the same time, in the water of the wells up to 8 agricultural pollutes were simultaneously detected in the water of wells, the total effect of which on the human body has not been studied. Evaluated the impact of content of pesticides in groundwater on the incidence rate of the population of Ukraine.

Is necessary control and strict regulation of the volumes of one or another class of pesticide preparations when applied to farmland is required. Needs regular monitoring of groundwater quality is required. New data on the levels of pollution of environmental objects with pesticides should be compared with (exceeding the maximum permissible concentration). If the levels of pollution of natural environment objects will increase (exceeding the maximum permissible concentration) then it is necessary to reduce to load of pesticides on agricultural lands and replace old pesticides with new ones. Formation of a balanced environmental management system in the context of sustainable development and the introduction of environmental and innovative technologies in agriculture.

Formation and implementation of modern mechanisms of national environmental policy.

Keywords: groundwater, organochloric pesticids, health.

\section{Введение}

Массивное применение пестицидов в сельском хозяйстве, начиная с 70-х годов XX века, сопровождалось мощным и непрерывно возрастающим прессом на биосферу.

К рубежу 1980-1990 гг. в минеральных и питьевых подземных водах обнаружено 15 \% применяемого ассортимента пестицидов. При этом в одной пробе обнаруживали до 8-10 пестицидов различных классов.
При обследовании подземных вод Украины, выполненном "Укргеологией" в 1986-1987 гг., пестициды были обнаружены на 86 \% общего количества опробованных участков на глубинах до 370 м [10]. Было найдено до 20 пестицидов различных классов - стойкие хлорорганические пестициды (ХОП) - ДДТ и его метаболиты, ГХЦГ и его изомеры; фосфорорганические пестициды (ФОП) - фосфамид, фозалон, метафос, карбофос, хлорофос; сим-триазины - симазин, атразин, прометрин. Цифра “20” условная, поскольку лаборатории "Укргеологии” могли определять 
лишь около 30 пестицидов из примерно 200, применяемых тогда в Украине.

В период 1960-1990 гг. в Украине наблюдался рост валового использования пестицидов с 4,5 тыс. т по действующему веществу (д. в.) в 1960 г. до 104 тыс. т по д. в. в 1990 г. За этот период на сельхозугодья Украины поступило более 1 млн 464 тыс. т ядохимикатов [3], а в целом с 1960 г. по 2011 г. 2 млн 85 тыс. т пестицидов [4].

В 1991 г. в Украине был принят закон “Об охране окружающей природной среды.' Нагрузки пестицидов на грунты сельхозугодий превысили защитные свойства природной среды, что привело к их попаданию в подземную геосистему. Этот пестицидный пресс сегодня сравним с индустриальным загрязнением, влиянием энергетики и транспорта на окружающую среду. Пестициды стали одним из важнейших факторов риска для жизни и здоровья человека, и всей живой природы. Поступление пестицидов в подземные воды, используемые для хозяйственно-питьевого водоснабжения, лечебных целей, особенно сказывается на здоровье и продолжительности жизни человека. В техногенно загрязненных регионах выявлена тесная корреляционная связь между загрязненностью почв и такими видами заболеваний, как аллергологические, стоматологические, желудочно-кишечного тракта [17].

Содержание пестицидов в подземных водах хозяйственнопитьевого и культурно-бытового водопользования определяли санэпидемстанции. Исследования проводили не систематически, без мониторинга загрязнения подземных вод пестицидами.

Проблема качества питьевой воды была и остается актуальной и чрезвычайно острой. Цель - изучение количественного и качественного состава пестицидов в подземных водах Украины и минимизация негативного воздействия пестицидов на организм человека. В настоящей статье обобщены данные качественного и количественного содержания пестицидов в подземных водах различных регионов Украины, полученные газохроматографическим методом. Изучены пути миграции, накопления пестицидов в жидкой фазе и их влияние на организм человека. "Загрязнение воды из-за неустойчивых методов ведения сельского хозяйства представляет серьезный риск для здоровья людей, экосистем планеты. Проблема часто недооценивается, как политиками, так и фермерами. Известны случаи загрязнения водопроводной воды пестицидами и удобрениями и негативного влияния сельскохозяйственных загрязнителей на здоровье населения" [11]. Определение FAO устойчивого развития сельского хозяйства (FAO Продовольственная и сельскохозяйственная организация Объединенных Наций). "Устойчивое развитие - это управление базой природных ресурсов, сохранение ее и ориентация технологических и институциональных изменений таким образом, чтобы обеспечить достижение и дальнейшее удовлетворение потребностей человека для настоящего и будущих поколений. Такое устойчивое развитие (в секторах сельского хозяйства, лесоводства и рыболовства) сохраняет генетические ресурсы Земли, воды, растений и животных, является экологически не ухудшающимся, технологически приемлемым, экономически жизнеспособным и социально оптимальным" [15].

В Швейцарии, в регионах, где ведется интенсивная сельскохозяйственная деятельность, пробы воды оказались загрязненными пестицидами. В общей сложности, загрязненную воду потребляют 2,7 \% населения - это примерно 170 тыс. человек. В 11 пробах было обнаружено повышенное количество продуктов распада хлороталонина. Это фунгицид для борьбы с грибковыми заболеваниями растений. В 2017 году, например, для обработки швейцарских полей было использовано 45 тонн хлороталонина. Вещество токсично для человека и животных: некоторые из его метаболитов канцерогенны. По этой причине пестицид был запрещен в ЕС. Атразин - еще один пестицид, содержание которого превышает допустимые значения в некоторых пробах. Он был запрещен еще семь лет назад, но его следы до сих пор присутствуют в питьевой воде. В большинстве проб питьевой воды были найдены следы (до 19 различных веществ в одном образце) в невысокой концентрации. Наличие глифосата или продуктов его распада не было выявлено. Ассоциация кантональных химиков считает, что качество питьевой воды в Швейцарии хорошее, но подчеркивает, что его надо улучшить в регионах, где занимаются сельским хозяйством. Швейцарские химики настаивают на принятии политических мер, направленных на ограничение или запрещение использования продуктов, загрязняющих подземные воды. В частности, они требуют, чтобы химические вещества, которые долгое время остаются в водах, разрешалось применять только при соблюдении строгих условий или не разрешалось вовсе [8].

Принцип принятия мер предосторожности более часто упоминается в общих политических программах. Одна из этих программ - 6-я Экологическая программа действий (6-th ЕАР) “Окружающая среда 2010: наше будущее, наш выбор”. Программа декларирует: “Необходим целостный и всесторонний подход к окружающей среде и здоровью с тем, чтобы предосторожность и предотвращение риска были в центре этой политики, принимающей во внимание особенно уязвимые группы населения, такие как дети и пожилые люди... Предотвращение и предосторожность также означают, что мы должны стремиться к замене использования опасных веществ менее опасными везде, где только это технически и экономически выполнимо”.

Обращение к Принципу принятия мер предосторожности по отношению к пестицидам в пределах 6-ой Экологической программы действий имеется в области охраны питьевой воды: “...уже существуют строгие стандарты по качеству питьевой воды относительно загрязнения пестицидами, и существует очевидная потребность в первую очередь прекратить попадание пестицидов в источники питьевой воды” [6].

Сокращение использования и принципы замены (the substitution principle) предложены только для самых опасных пестицидов, которые конкретно не определены на этой стадии.

Действия по поводу пестицидов, предлагаемые 6-th EAP.

Кодекс наилучшей практики по использованию пестицидов.

1. Пересмотр Директивы 91/44 по регистрации пестицидов.

2. Тематическая стратегия сообщества по устойчивому использованию пестицидов. Эти действия будут включать:

а) минимизацию рисков, связанных с использованием пестицидов, преимущественно определяемых токсичностью веществ, и мониторинг достигаемого прогресса;

б) улучшение контроля в отношении использования и распределения пестицидов;

в) замену наиболее опасных активных веществ более безопасными, включая нехимические альтернативы;

г) поощрение сельского хозяйства с низким применением пестицидов или свободного от пестицидов, и использование комплексных стратегий борьбы с вредителями (КСБ, integrated pest management, IPM).

Устранение запасов устаревших пестицидов [11-14].

\section{Результаты и их обсуждение}

Целенаправленные многолетние исследования позволили рассмотреть статистическое и динамическое распределе- 
ние пестицидных препаратов в подземных водоносных горизонтах. Всего в подземных водах Украины нами обнаружено порядка 20 наименований пестицидов и их метаболитов, производных различных классов соединений: хлорорганических (ХОП) - п,п'-ДДТ, о,п'-ДДД, п,п'-ДДЕ, $\alpha$-ГХЦГ, $\beta$-ГХЦГ, $\gamma$-ГХЦГ, альдрин, гептахлор; сим-триазинов - симазин, атразин, прометрин, пропазин; группы 2,4-Д; фосфорорганических (ФОП) - рогор (фосфамид, БИ-58), метафос, карбофос, фозалон и др. Однако, указанный перечень содержащихся в подземных водах пестицидов, по всей вероятности, далеко не полный.

В 90-х годах в Украине использовалось в общей сложности порядка 200 разновидностей пестицидов, примерно 30 из которых определялись в лабораториях. Остальные не исследовались в связи со сложностями информационного, методического и финансового характера. Ниже обобщены результаты 1900 анализов подземных вод, выполненные автором по договорам на лабораторной базе ИГН НАНУ и Института экогигиены и токсикологии им. Л. И. Медведя (2001 г.), использованы также материалы фондов, литературных источников. По двум водоносным горизонтам - четвертичных и эоценовых отложений Киевской области - обобщены результаты анализов, выполненные автором, в отделе гидрогеологических проблем ИГН НАНУ по теме исследований под руководством академика НАНУ В. М. Шестопалова (таблица).

В таблице представлены среднестатистические (максимальные и минимальные) значения содержания пестицидов в водоносных горизонтах геологических отложений разного возраста.

Водоносныйгоризонтчетвертичныхотложенийсодержит стойкие ХОП на 1-2 порядка меньше, чем более глубоко расположенные водоносные горизонты меловых, юрских и триасовых отложений. Это свидетельствует о длительной циркуляции пестицидов в подземной геосистеме, вертикальной и горизонтальной миграции пестицидов. По нашим расчетам (за 10-летний период), среднестатистическая концентрация ХОП в основных водоносных горизонтах Украины составляет по сумме ДДТ $3,6 \cdot 10^{-5}$ мг/дм ${ }^{3}$; по сумме ГХЦГ $-3 \cdot 10^{-5}$ мг/дм ${ }^{3}$. Наибольшее загрязнение пестицидами обнаружено в водоносных горизонтах подземных вод южной и центральной Украины, гораздо меньшее загрязнение наблюдается в во- доносных горизонтах западного, восточного и северного регионов страны.

Результаты проведенных исследований свидетельствуют о том, что содержание пестицидов в подземных водах не остается постоянным, а претерпевает закономерные изменения во времени как в многолетнем цикле, так и по сезонам года. В многолетнем цикле на различных участках отмечается в одних случаях рост, в других - снижение концентрации отдельных пестицидов в подземных водах, что вызвано, по всей вероятности, изменением ассортимента и нагрузок пестицидов на разных территориях. Ретроспективное загрязнение подземных вод ДДТ постепенно снижается. ГХЦГ продолжают применять на сельхозугодьях.

Как показал анализ конкретных материалов, основными источниками загрязнения подземных вод пестицидами являются почвы сельхозугодий, территории размещения складов предприятий - изготовителей ядохимикатов, места захоронения пестицидов, растворные узлы, загрязненные поверхностные воды и т. д.

За 2005-2007 гг. было зарегистрировано (перерегистрировано) 1112 наименований пестицидов и агрохимикатов [5]. Новые поколения пестицидов - класс инсектицидов неоникотиноиды; класс пестицидов стробилурины “молодая" группа контактных фунгицидов со специфическим механизмом действия; класс сульфонилмочевины относятся к селективным наземным гербицидам гормонального типа, подавляют образование аминокислот изолейцина и валина. Неоникотиноидные инсектициды подавляют активность ацетилхолинэстеразы, являются агонистами никотин-ацетилхолиновых препаратов. Безвредны для растений, но, возможно, вызывают массовую гибель пчел. Еврокомиссия запретила применение инсектицидов на основе трех субстанций - тиаметоксама, клотианидина, имидаклоприда на два года: ученым предстоит доказать или опровергнуть наличие причинно-следственной связи между применением неникотиноидов и гибелью пчел.Некоторые часто используемые фунгициды (пестициды, уничтожающие патогенные грибы), попадая в организм человека, вызывают изменения на уровне ДНК, вплоть до аутизма, болезни Альцгеймера и др. неврологических заболеваний. В этот класс пестицидов вошли ротенон, пиридабен, фенпироксимат, фамоксадон, пираклостробин,

Таблица. Содержание хлорорганических и др. пестицидов в подземных водах Украины, мг/дм³

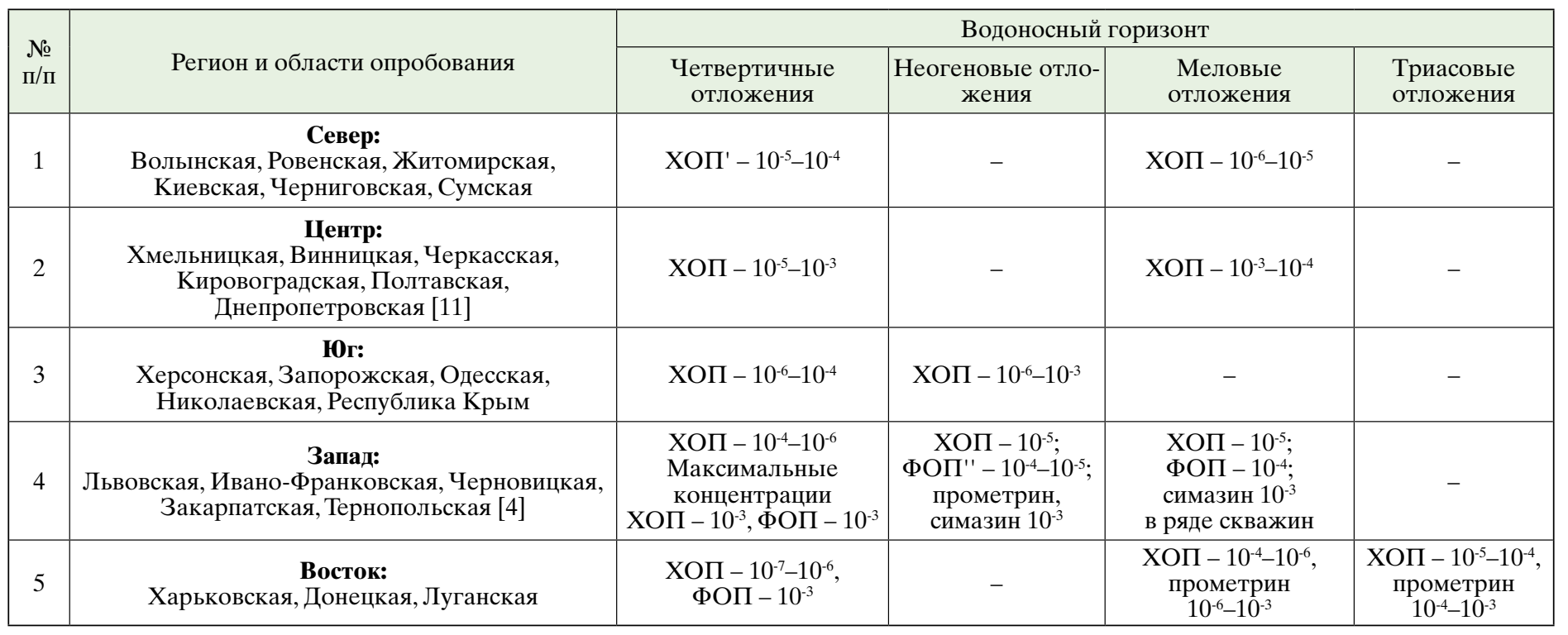

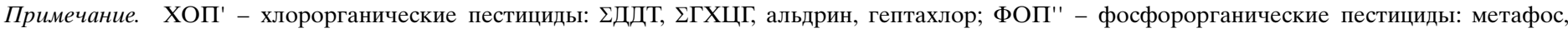
карбофос, фозалон, рогор; сим-триазины: симазин, прометрин. 
фенамидон. Вывод: если придерживаться установленных агротехнических и гигиенических нормативов и регламентов использования новых препаратов, то их негативное действие на организм человека можно минимизировать.

Сегодня особенно актуальной является проблема предотвращения загрязнения пестицидами питьевой воды и продуктов питания. Попадая разными путями в организм человека, пестициды могут вызывать нежелательные последствия. Пестициды вызывают гибель многих организмов и могут при накоплении в грунте, сельскохозяйственной продукции ухудшать состояние здоровья человека [3]. Применение пестицидов второго поколения в сельскохозяйственном производстве вызывает интоксикацию организма человека, общее его отравление. Фосфорорганические соединения вызывают нарушения функций сердечно-сосудистой системы, расширение кровеносных сосудов, становятся причиной головной боли и т. д. Хлорорганические соединения негативно влияют на центральную нервную систему, верхние дыхательные пути и работу печенки. Но, несмотря на вредное влияние пестицидов, они используются в сельском хозяйстве и являются основным средством борьбы с вредителями, болезнями сельскохозяйственных культур и бурьянами.

Особое внимание следует уделить тому факту, что в воде скважин одновременно обнаружено до восьми сельскохозяйственных загрязнителей, суммарный эффект действия которых на организм человека не изучен. При комплексном и комбинированном поступлении препаратов в организм человека может иметь место не “суммирование,'а “потенцирование” их токсического действия. В связи с этим может наблюдаться выраженное токсическое действие пестицидов даже при их поступлении в организм человека в количествах, не превышающих допустимые дозы.

На состояние здоровья населения оказывает влияние годовая нагрузка пестицидов на площадь сельхозугодий Украины кг/га по действующему веществу (д. в.). При использовании пестицидов на полях сельхозугодий происходит загрязнение пестицидами питьевой воды, продуктов питания, воздуха данного региона. Поэтому необходим контроль и строгая регламентация объемов того или иного класса пестицидов при внесении их на поля. В 1959 г. на душу населения в Украине приходилось 5 кг химических препаратов, употребляемых в сельском хозяйстве, детей с генетическими отклонениями рождалось $0,74 \%$ от общего числа [1]. В 1983 г. масса химических препаратов, поступающих на поля сельхозугодий в Украине, возросла до 25 кг на душу населения. Число детей, родившихся с генетическими нарушениями, возросло до 16,5 \%. Отличительной особенностью хлорорганических пестицидов является увеличение их концентрации в дальнейших звеньях биологической цепи. Таким образом, прослеживается определенная взаимосвязь между распространением загрязнения пестицидами различными путями миграции и типом заболеваний населения. Несомненно, что здоровье и риск возникновения заболеваний среди всего населения, в том числе отдельного человека, зависят от состояния окружающей природной среды, к основным элементам которой относятся почва, вода и воздух.

Источниками централизованного водоснабжения в Украине являются поверхностные и подземные воды, доля которых составляет 68 \% и $32 \%$ соответственно. Из результатов обобщения следует, что 70 \% поверхностных и 30 \% подземных вод в Украине утратили питьевое значение и перешли в категории загрязненности - “условно чистая” и “загрязненная”.

Поэтому развитие заболеваний неинфекционной природы определяется в основном содержанием в воде химиче- ских примесей, наличие и количество которых обусловлено техногенными и антропогенными факторами.

Нами обнаружена взаимосвязь между применением инсектицидов и количеством онкологических заболеваний. При сопоставлении собственных данных по среднегодовому применению инсектицидов (тонн д. в.) (1960-1990 гг.) и данных по количеству злокачественных новообразований (ЗНО) чел./100 тыс. населения за 1996 г. получены значимые коэффициенты корреляции [7], а именно: при раке молочной железы $\mathrm{K}=0,82$; ЗНО органов дыхания $\mathrm{K}=0,69$; ЗНО меланомой и др. заболеваниями кожи $\mathrm{K}=0,74$.

Среднегодовое применение инсектицидов и гербицидов в тоннах д. в. за 1960-1990 гг. сопоставимо с общей заболеваемостью ЗНО чел./на 100 тыс. населения в 1991, 1995, 1996 годах. Практически непрерывный рост заболеваемости ЗНО в Украине и Одесской обл. (наиболее высокий показатель ЗНО на 100 тыс. чел.) наблюдается за период с 1980 по 1999 гг. (рис.1).

Начиная с 1992 г. в Украине и в Одесской области отмечается снижение темпов роста заболеваемости, хотя заболеваемость в целом продолжает увеличиваться.

Результаты анализа распределения показателя онкозаболеваемости по областям Украины (рис. 2) подтвердили значительные его изменения, произошедшие в 1991-1999 гг., по сравнению с 1968-1972 гг. (первая половина периода химизации сельскохозяйственного производства) [7]. Наиболее высокие уровни заболеваемости ЗНО в первый этап этого периода были характерны преимущественно для областей с развитой

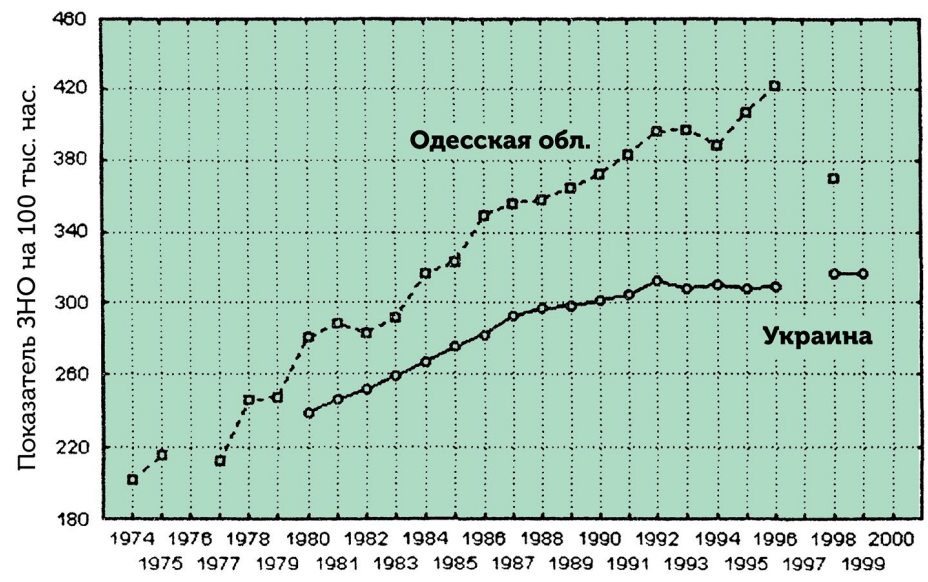

Рис. 1. Динамика заболеваемости населения злокачественными новообразованиями в Одесской области и в целом по Украине

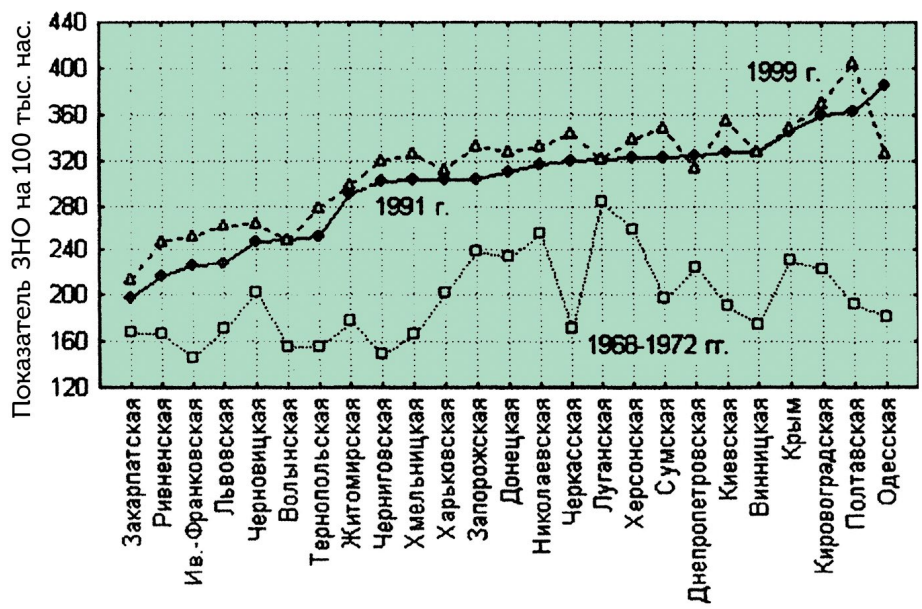

Рис. 2. Распределение показателя онкологических заболеваний по областям Украины в 1968-1972 гг., 1991 и 1999 гг. 
горнодобывающей промышленностью - Запорожской, Донецкой, Луганской. А среди областей с преобладанием сельскохозяйственного производства повышенная заболеваемость $3 \mathrm{HO}$ прослеживалась в Николаевской и Херсонской областях.

По состоянию на 1991 и 1999 гг. уровни заболеваемости повсеместно выросли, при этом лидируют по этому показателю области с преобладанием аграрного сектора - Кировоградская, Полтавская, Одесская.

Нагрузки соответствующих групп пестицидов кг/га в год пропорциональны отдельным нозологическим формам и группам патологий на 10 тыс. человек [9]. Наибольший суммарный риск имеют такие нозологические формы: хронические заболевания миндалин и аденоидов, острые инфекции верхних дыхательных путей, грипп; пневмонии у детей до 1 года; пневмонии у недоношенных детей. Оценки риска также показывают, что самое высокое влияние пестицидов на заболеваемость населения отдельными нозологическими формами и группами патологий характерно для хлорорганических пестицидов, высокое - для медьсодержащих пестицидов, среднее - для фосфорорганических пестицидов и карбаматов, низкое - для гербицидов и остальных препаратов.

\section{Заключение}

В воде скважин различной глубины одновременно обнаружено от 3 до 8 сельскохозяйственных загрязнителей. Хлорорганические пестициды, поступающие в организм человека с питьевой и минеральной водами в концентрации, превышающей предельно допустимую, на фоне радиоактивного прессинга, вызывают негативные последствия в виде различных заболеваний химической этиологии (интоксикация, канцерогенное, мутагенное и тератогенное действие).

Загрязненная химикатами вода может быть причиной аллергических заболеваний, разных нарушений обмена веществ, заболеваний органов дыхания, сердечно-сосудистой системы и онкологических заболеваний. Даже при концентрации пестицидов в питьевой воде, не превышающей предельно допустимую, пестициды также представляют потенциальную опасность, потому что суммарный эффект их действия на организм человека не изучен. По нашему мнению, пестициды потенцируют действие антропогенных загрязнителей (радионуклидов, тяжелых металлов и др.) и оказывает негативное влияние на генетическую и иммунную системы человека. Необходим контроль и строгая регламентация объемов того или иного класса пестицидных препаратов при внесении их на сельхозугодья. Необходим регулярный контроль качества подземных вод. Необходим мониторинг загрязнения подземных вод и других объектов природной среды пестицидами.

Если уровни загрязнения объектов природной среды будут увеличиваться (превышение предельно допустимой концентрации), то нужно уменьшать нагрузки пестицидов на полях и заменять старые пестициды новыми. С целью минимизации отрицательных последствий накопления пестицидов на территории Украины и их влияния на подземную геосистему следует проводить оценку риска антропогенно загрязненных территорий.

Необходимо формирование сбалансированной системы природопользования в контексте устойчивого развития и внедрение экологических и инновационных технологий в сельском хозяйстве.

\section{ЛИТЕРАТУРА}

1. Бондар О. I., Коваленко О. М., Ткач В. М., Федоренко О. I Вплив довкілля на людину і імунологія. Навчальний посібник. ДЕІ-ГТІ. - К. -Х., 2005. - 95 c.
2. Ежегодник содержания остаточных количеств пестицидов в объектах природной среды отдельных регионов Советского Союза. Книга I, II. - Обнинск: Госкомгидромет, 1988. - 186 с., 132 с.

3. Залеський I. I., Клименко М. О. Екологія людини. Видавничий центр “Академія”.- К., 2005. - 287 с.

4. Осокина Н. П. Содержание остаточных количеств пестицидов в подземных водах и других объектах природной среды отдельных регионов Украины. Издатель Кравченко Я. О. - К., 2019. - 190 с.

5. ПЕРЕЛІК пестицидів і агрохімікатів, дозволених до використання в Україні за 2008 рік. - К: Юнівест Медіа, 2008. - 448 с.

6. Пособие для НПО стран Центральной и Восточной Европы... и не только. - Гамбург, 2003. -47 с.

7. Ротарь М. Ф., Лиходедова О. Г. Пестициды в геологической среде и некоторые последствия их применения в Украине: Монография. - Одесса: ІНВАЦ, 2007. - 170 с.

8. Салимова 3. Пестициды в питьевой воде "Nashagazta.ch" 7.04.2021.

9. Tхор I. I., Петрук Р. В. Аналіз техногенних ризиків від зберігання накопичених пестицидних препаратів у Вінницькій області// Екологічний вісник. - 2008. - № 3 (49). - 32 с.

10. Яковлев Е. А. Геолого-экологические аспекты химизации сельского хозяйства//Проблемы обоснования и реализации мероприятий по минимизации негативного воздействия на подземные воды сельскохозяйственных загрязнений. - К., 1989. - С. 5-8.

11. Commission Directive 1999/50/EC of 25 May 1999 amending Directive 91/321/EEC on infant formulae and follow - on formulae, Official Journal L 139/29.

12. European Commission (2001): Communication from the Commission to the Council, The European Parliament, the Economic and Social Committee and the Committee of the Regions. On the sixth environment action programme of the European Community, Environment 2010: Our choice - The Sixth Environment Action Programme - Proposal for a Decision on the European Parliament and of the Council Laying Down, The Community Environment Action Programme 2000-2010.

13. European Commission (2003): Commission Directive 2003/13/ EC amending Directive 96/5/EC on processed cereal-based foods and baby foods for infants and young children, Official journal L 41/33.

14. European Commission (2003): Commission Directive 2003/14/ EC amending Directive 91/321/EC on infant formulae and follow - on formulae, Official journal L 41/37.

15. http://www.fao.org/3/w2598e/w2598e04.htm Google снимок страницы по состоянию на 18.05.2020 GMT.

16. Mateo-Caracta Xaver J. Water pollution from agriculture: a gobal review. - 2018. - 404 p. www. unwater. org $>$ water-pollution-fromagriculture-a-...23.07. 2018. www.fao.org $>23.07 .2018$

17. Molozhanova E., Osokina N., Kostikov I., Molozhanov I. New approaches to bioindication at the assessment of anthropogenetic soil pollution//NATO Advanced Research Workshop. - M., 1995. - P. 28.

18. Osokina N. P. Pesticides concentrations in the environment at the health resorts in the central part of Ukraine//Fifth SETAC-Europe Congress Copenhagen 25-28, June 1995. Environmental science and vulnerable ecosystems. - C., 1995. - P. 241.

19. World Health Organization/International Programme on Chemical Safety (2001): Inventory of IPCS and other WHO pesticide evaluation and summary of toxicological evaluations performed by the Joint Meeting of Pesticide Residues (JMPR) through 2001, WHO/IPCS, Vienna, Swizerland.

\section{REFERENCES}

1. Bondar O. I., Kovalenko O. M., Tkach V. M., Fedorenko O. I. The impact of the environment on humans and immunology. - Kyiv-Kharkiv, 2005. - 95 p. (In Ukrainian).

2. Yearbook of the content of residual amounts of pesticides in the natural objects of certain regions of the Soviet Union. Book I, II. - Obninsk: Goskomgidromet, 1988. - 186 p., 132 p. (In Russian).

3.Zaleskyi I. I., Klymenko M. O. Human ecology. - Kyiv:Vydavnychyi tsentr "Akademiia",2005. - 287 p. (In Ukrainian).

4. Osokina N. P. The content of residual amounts of pesticides in groundwater and other objects of the natural environment of certain regions of Ukraine. - Kiev, 2019. - 190 p. (In Russian).

5. List of pesticides and agrochemicals approved for use in Ukraine in 2008. - Kyiv: Univest Media, 2008. - 448 p. (In Ukrainian).

6. A Handbook for NGOs in Central and Easten Europe... and More. - Gamburg, 2003. - 47 p. (In Russian). 
7. Rotar M. F, Lihodedova O. G. Pesticides in the geological environment and some of the consequences of their use in Ukraine. - Odessa: INVAC, 2007. - 170 p. (In Russian).

8. Salimova Z. Pesticides in drinking water "Nashagazta.ch"7.04.2021. (In Russian).

9. Tkhor I. I., Petruk P. V. Analysis of manmade risks from the preservation of accumulated pesticides in Vinnytsia region//Ekolohichnyi visnyk. - 2008. - № 3 (49). - 32 p. (In Ukrainian).

10. Jakovlev E. A. Geological and ecological aspects of chemicalization of agriculture//Problemy obosnovaniya i realizacii meropriyatij po minimizacii negativnogo vozdejstviya na podzemnye vody selskohozyajstvennykh zagryaznitelej. - Kiev, 1989. - P. 5-8. (In Russian).

11. Commission Directive 1999/50/EC of 25 May 1999 amending Directive 91/321/EEC on infant formulae and follow - on formulae, Official Journal L 139/29.

12. European Commission (2001): Communication from the Commission to the Council, The European Parliament, the Economic and Social Committee and the Committee of the Regions. On the sixth environment action programme of the European Community, Environment 2010: Our choice - The Sixth Environment Action Programme Proposal for a Decision on the European Parliament and of the Council Laying Down, The Community Environment Action Programme 2000-2010.

13. European Commission (2003): Commission Directive 2003/13/ EC amending Directive 96/5/EC on processed cereal-based foods and baby foods for infants and young children, Official journal L 41/33.

14. European Commission (2003): Commission Directive 2003/14/ EC amending Directive 91/321/EC on infant formulae and follow - on formulae, Official journal L 41/37.

15. http://www.fao.org/3/w2598e/w2598e04.htm Google снимок страницы по состоянию на 18.05.2020 GMT.

16. Mateo-Caracta Xaver J. Water pollution from agriculture: a gobal review. - 2018. - 404 p. www. unwater. org > water-pollution-from-agriculture-a-...23.07. 2018. www.fao.org $>23.07 .2018$

17. Molozhanova E., Osokina N., Kostikov I., Molozhanov I. New approaches to bioindication at the assessment of anthropogenetic soil pollution//NATO Advanced Research Workshop. - M., 1995. - P. 28.

18. Osokina N. P. Pesticides concentrations in the environment at the health resorts in the central part of Ukraine//Fifth SETAC-Europe Congress Copenhagen 25-28, June 1995. Environmental science and vulnerable ecosystems. - C., 1995. - P. 241.

19. World Health Organization/International Programme on Chemical Safety (2001): Inventory of IPCS and other WHO pesticide evaluation and summary of toxicological evaluations performed by the Joint Meeting of Pesticide Residues (JMPR) through 2001, WHO/IPCS, Vienna, Swizerland.

Рукопи с о тримано 30.04.2021.

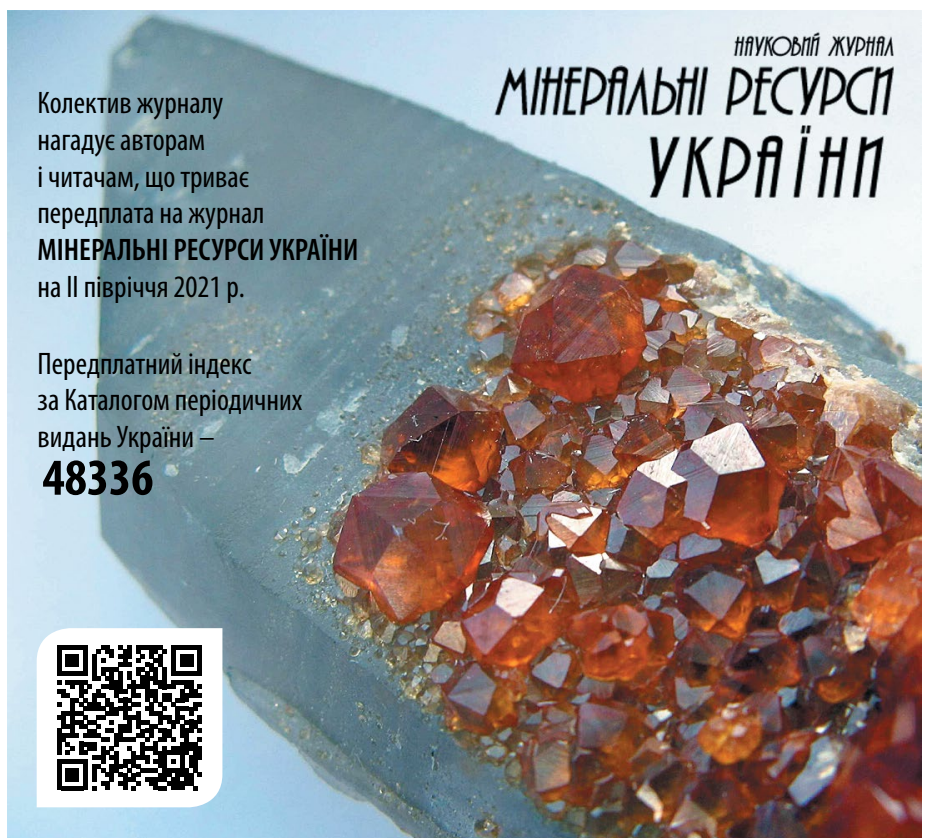

ДО ВІДОМА ABTOPIB MIHEPIILDHII PECYPCH
YKPAIIHII

\section{ДЛЯ ДАЛЬШОГО ПІДВИЩЕННЯ НАУКОВОГО РЕЙТИНГУ ЖУРНАЛУ ТА ЙОГО ДОПИСУВАЧІВ ВАРТО ЗВЕРНУТИ УВАГУ НА ТАКЕ:}

1. Кожна публікація не англійською мовою супроводжується анотацією англійською мовою обсягом не менш як 1800 знаків (з ключовими словами). Якщо видання не $\epsilon$ повністю українськомовним, кожна публікація не українською мовою супроводжується анотацією українською мовою обсягом не менш як 1800 знаків (з ключовими словами, ураховуючи пропуски).

2. Вимоги до анотацій англійською мовою: інформативність (без загальних слів); змістовність (відображення основного змісту статті та результатів досліджень); застосування термінології, характерної для іноземних спеціальних текстів; єдність термінології в межах анотації; без повторення відомостей, що містяться в заголовку статті.

3. Прізвища авторів статей надаються в одній із прийнятих міжнародних систем транслітерації (з української - відповідно до Постанови Кабінету Міністрів України № 55 від 27.01.2010“Про впорядкування транслітерації українського алфавіту латиницею", з російської - відповідно до "Системы транслитерации Библиотеки конгресса США"). Зазначення прізвища в різних системах транслітерації призводить до створення в базі даних різних профілів (ідентифікаторів) одного автора.

4. Для повного й коректного створення профілю автора дуже важливо зазначити місце його роботи. Дані про публікації автора використовуються для отримання повної інформації щодо наукової діяльності організацій і загалом країни. Застосування в статті офіційної, без скорочень, назви організації англійською мовою запобігатиме втраті статей у системі аналізу організацій та авторів. Бажано вказати в назві організації відомство, якому вона підпорядковується.

5. В аналітичній системі SCOPUS потрібні пристатейні списки використаної літератури латиницею. Можливості SCOPUS дають змогу проводити такі дослідження: за покликаннями оцінювати значення визнання робіт конкретних авторів, науковий рівень журналів, організацій і країн загалом, визначати актуальність наукових напрямів і проблем. Стаття з представленим списком літератури демонструє професійну ерудицію та якісний рівень досліджень її авторів.

6. Правильний опис джерел, на які покликаються автори, $\epsilon$ запорукою того, що цитовану публікацію буде враховано в процесі оцінювання наукової діяльності їі авторів, а отже й організації, регіону, країни. За статистикою цитування журналу визначають його науковий рівень, авторитетність тощо. Тому найважливішими складниками в бібліографічних покликаннях $€$ прізвища авторів і назви журналів. До опису статті треба вносити імена всіх авторів, не скорочуючи їхньої кількості. Для уникнення неточностей в ідентифікації авторства й визначення персональних метрик (показників) бібліометрії авторам наукових публікацій потрібно використовувати персональні коди ORCID.

7. Для українсько- та російськомовних статей з журналів, збірників, матеріалів конференцій структура бібліографічного опису така: автори (транслітерація), переклад назви статті англійською мовою, назва джерела (транслітерація), вихідні дані, у дужках - мова оригіналу, ідентифікатор DOI.

8. Список використаної літератури (References) для SCOPUS та інших закордонних баз даних наводиться повністю окремим блоком, повторюючи список літератури, що подається українською/ російською мовою, незалежно від того, містяться в ньому чи ні іноземні джерела. Якщо в списку $є$ покликання на іноземні публікації, їх повністю повторюють у списку, який створюють латиницею.

Рукопис статті до редакції автори подають зі своїми підписами. 